DOI: $10.29303 /$ jrpb.v8i2.182

ISSN 2301-8119, e-ISSN 2443-1354

Tersedia online di http://jrpb.unram.ac.id/

\title{
ANALISIS VARIABILITAS SPASIAL HUJAN BULANAN DAN TAHUNAN MENGGUNAKAN HISTOGRAM, VORONOI, DAN METODE INTERPOLASI
}

\author{
Spatial Variability Analysis of Annual and Monthly Rainfall \\ using Histogram, Voronoi, and Interpolation Methods
}

\section{Rufiani Nadzirah, Rafika Yulfia PIR, Indarto Indarto*)}

Program Studi Teknik Pertanian, Fakultas Teknologi Pertanian, Universitas Jember J1. Kalimantan Nomor 37 Kampus Tegalboto, Jember 68121, Indonesia

\author{
Email $^{*}$ : indarto.ftp@unej.ac.id \\ Diterima: Juli 2020 \\ Disetujui: September 2020
}

\begin{abstract}
Analysis of spatial variability is used to study the variability of rainfall received in a specific geographical area. The analysis may use to describe the spatial distribution of rainfall, determine planting schema, mitigation of flood, drought, and hydro-meteorological related disaster. This research study research analyzed spatial variability of annual and monthly rainfall in the area that covers three regencies (Jombang, Kediri, and Nganjuk). The daily rainfall data explored in this study was from 1990 to 2016 and collected from 137 measurement sites. The research procedure was (1) data processing, (2) Exploratory Spatial Data Analysis (ESDA) using histograms, Voronoi-maps, and Normal QQ-plots, (3) interpolation, and (4) regression and correlation tests. The result showed that rainfall data did not follow the normal distribution. The standard deviation value was $126.9 \mathrm{~mm}$ for monthly and $629.1 \mathrm{~mm}$ for annual rainfall. The produced thematic map showed that most of the area has monthly rainfall between 621 - $760 \mathrm{~mm} / \mathrm{month}$ and annual rainfall between 2178 - $3202 \mathrm{~mm} /$ year. Regression and correlation tests showed a strong correlation between the altitude of location and the amount of annual and monthly rainfalls received.
\end{abstract}

Keywords: ESDA; monthly-rainfall; annually-rainfall; spatial, variability

\begin{abstract}
ABSTRAK
Analisa variabilitas spasial digunakan untuk mempelajari variablitas hujan yang diterima pada luasan tertentu. Analisis tersebut juga dapat digunakan untuk menentukan kalender tanam, mitigasi banjir, kekeringan, dan potensi bencana hidro-meteorologi terkait. Penelitian ini bertujuan menganalisis variabilitas spasial hujan bulanan dan tahunan di wilayah Kabupaten Jombang, Kediri, dan Nganjuk. Data diperoleh dari 137 stasiun hujan dengan panjang rekaman data dari tahun 1990 sampai dengan 2016. Tahap penelitian mencakup: (1) pengolahan data, (2) Exploratory Spatial Data Analysis (ESDA) menggunakan tool histogram, Voronoi-map dan Normal QQ-plot, (3) interpolasi, dan 4) analisis regresi-korelasi. Hasil analisis menunjukkan bahwa data hujan yang digunakan tidak terdistribusi normal. Nilai standar deviasi $126,9 \mathrm{~mm}$ untuk hujan bulanan dan $629,1 \mathrm{~mm}$ untuk hujan tahunan. Peta tematik menunjukkan bahwa sebagian besar wilayah penelitian menerima hujan bulanan maksimum $621-760 \mathrm{~mm} / \mathrm{bulan}$,
\end{abstract}


dan mengalami hujan tahunan maksimum 2.178 - $3.202 \mathrm{~mm} / \mathrm{tahun}$. Analisis korelasi regresi menunjukkan adanya hubungan yang kuat antara ketinggian tempat dengan besarnya hujan yang diterima.

Kata kunci: ESDA; hujan-bulanan; hujan-tahunan; spasial; variabilitas

\section{PENDAHULUAN}

\section{Latar Belakang}

Curah hujan memiliki variabilitas spasial yang spesifik untuk setiap wilayah. Variabilitas spasial dapat ditunjukkan oleh perbedaan hujan yang diterima per subwilayah tertentu pada interval waktu tahunan, bulanan, atau harian (Indarto, 2013a; Indarto, 2013b).

Studi tentang analisis variabilitas spasial hujan sudah umum dilakukan pada banyak tempat di berbagai belahan dunia. Coulibaly dan Becker (2007) dengan lokasi penelitian di Afrika Selatan telah membandingkan beberapa metode interpolasi spatial, antara lain Inverse Distance Weighting (IDW), ordinary kriging, universal kriging, dan cokriging. Hasil interpolasi terbaik dengan error terendah adalah pada metode ordinary kriging dengan hasil median error adalah 11\%. Ellouze et al. (2009) di Tunisia Selatan meneliti tentang variabilitas spasial dan temporal curah hujan. Metode yang digunakan adalah Principal Component Analysis (PCA), representation quality, dan metode regresi berganda. Hasil dari penelitian ini teridentifikasinya pola spasial hujan yang dipengaruhi oleh topografi dan pesisir.

Zhang \& Srinivasan (2009) di China melakukan penelitian tentang estimasi variabilitas spasial curah hujan untuk pemodelan hidrologi pada Daerah Aliran Sungai (DAS) Luohe di hilir Yellow River. Penggabungan dan pengembangan beberapa metode dilakukan pada penelitian ini antara lain poligon Thiessen, Nearest Neighborhood (NN), Inverse Distance Weighted (IDW), Simple Kriging (SK), Ordinary Kriging (OK), Simple Kriging with Local Means (SKlm), dan Kriging with External Drift (KED). Hasil yang diperoleh dari metode interpolasi tersebut adalah tinggi curah hujan rata-rata adalah berbeda tidak signifikan, akan tetapi untuk nilai dari curah hujan maksimum, dan curah hujan minimum berbeda signifikan. Kesimpulan lain dari penelitian ini adalah tidak ada metode interpolasi yang memberikan hasil yang lebih baik dari metode lainnya secara konsisten.

Salah satu faktor yang menyebabkan variasi hujan adalah perbedaan ketinggian tempat (elevasi). Feki et al. (2012) di Tunisia menggunakan data elevasi sebagai variabel sekunder untuk meningkatkan nilai akurasi dan estimasi distribusi curah hujan di Tunisia. Tobin et al. (2011) di Swiss juga memberikan hasil yang serupa, dimana penambahan elevasi sebagai informasi tambahan menghasilkan validasi terbaik.

Ada banyak metode terkait dengan pengolahan data yang bervariasi terhadap ruang secara statistik. Salah satunya adalah Exploratory Spatial Data Analysis (ESDA). ESDA dapat digunakan untuk memplotkan distribusi data, melihat kecenderungan global dan lokal, mengevaluasi autokorelasi spasial (spatial autocorrelation) memahami covarian diantara beberapa seri data (De Smith et al., 2007).

Analisa dalam bentuk grafik umumnya berupa: histogram, pie charts, box plots dan/atau scatter plot. Tidak satu pun grafik di atas menunjukkan secara eksplisit perspective spasial dari suatu seri-data, tetapi jika ada fasilitas untuk menghubungkan data tersebut dengan peta dan tabel, maka data-data tersebut dapat lebih bermakna untuk analis spasial. ESDA memfasilitasi analis tersebut. Pemilihan terhadap objek melalui linking dapat dilakukan secara otomatis (melalui pemrograman) atau didefinisikan oleh pengguna melalui grafik (De Smith et al., 2007; Indarto, 2013). Beberapa contoh tools 
statistik di dalam ESDA, misalnya: (1) Histogram dan (2) Normal QQ-Plot, (3) Voronoi-Map, (4) Thiessen Poligon, BoxPlot (De Smith et al., 2007).

Data untuk analisis variabilitas spasial juga dapat berasal dari berbagai metode pengukuran dan variabel iklim atau hidrometerologi yang berbeda. Misalnya, pada penelitian terdahulu, Haberlandt (2007) menggunakan data konvensional atau hasil pengukuran titik/lokal pada stasiun hujan. Selanjutnya, Ellouze et al. (2009) menggunakan data radar meteorologi untuk mempelajari variabilitas spasial dan interpolasi data. Johnston et al. (2001) menggunakan data iklim sebagai input untuk proses interpolasi. Moges et al. (2007) melakukan interpolasi untuk data hidroklimatologi. Interval waktu yang digunakan untuk analisis variabilitas spasial hujan juga dapat bervariasi dari jam-jaman, harian, bulanan, musiman, atau tahunan. Interpolasi data hujan tahunan dan bulanan untuk menggambarkan variabiitas spasial hujan bulanan dan tahunan juga dilakukan oleh Kampata et al. (2008); Coulibaly \& Becker (2007), dan Shiddiq et al. (2018).

Metode interpolasi Spline digunakan misalnya oleh Hutchinson (1998), Naoum \& Tsanis (2004), dan Pasaribu \& Haryani (2012). Selanjutnya, metode interpolasi IDW telah banyak digunakan misalnya dalam studi oleh Li \& Revesz (2004), Segond et al. (2007), Pasaribu \& Haryani (2012), Indarto (2013a; 2013b; 2011), dan Respatti et al. (2014). Interpolasi menggunakan metode IDW dapat memberikan hasil interpolasi yang lebih akurat dari pada metode lainnya dan juga lebih tepat digunakan dalam interpolasi spasial (Pramono, 2008). Metode interpolasi Kriging misalnya digunakan dalam studi oleh Arétouyap et al. (2016), Arfaini \& Handayani (2016), dan Respatti et al. (2014).

Berdasarkan penelitian sebelumnya, penelitian ini bertujuan menganalisis variabilitas spasial hujan dan mempelajari pengaruh topografi terhadap jumlah hujan menggunakan histogram, voronoi, dan metode interpolasi.

\section{METODE PENELITIAN}

\section{Lokasi Studi}

Penelitian ini dilakukan pada wilayah kerja UPT PSDA (Unit Pelaksana Teknis Pengelola Sumber Daya Air) di Kediri yang meliputi tiga kabupaten yaitu: Jombang, Kediri, dan Nganjuk (Gambar 1).

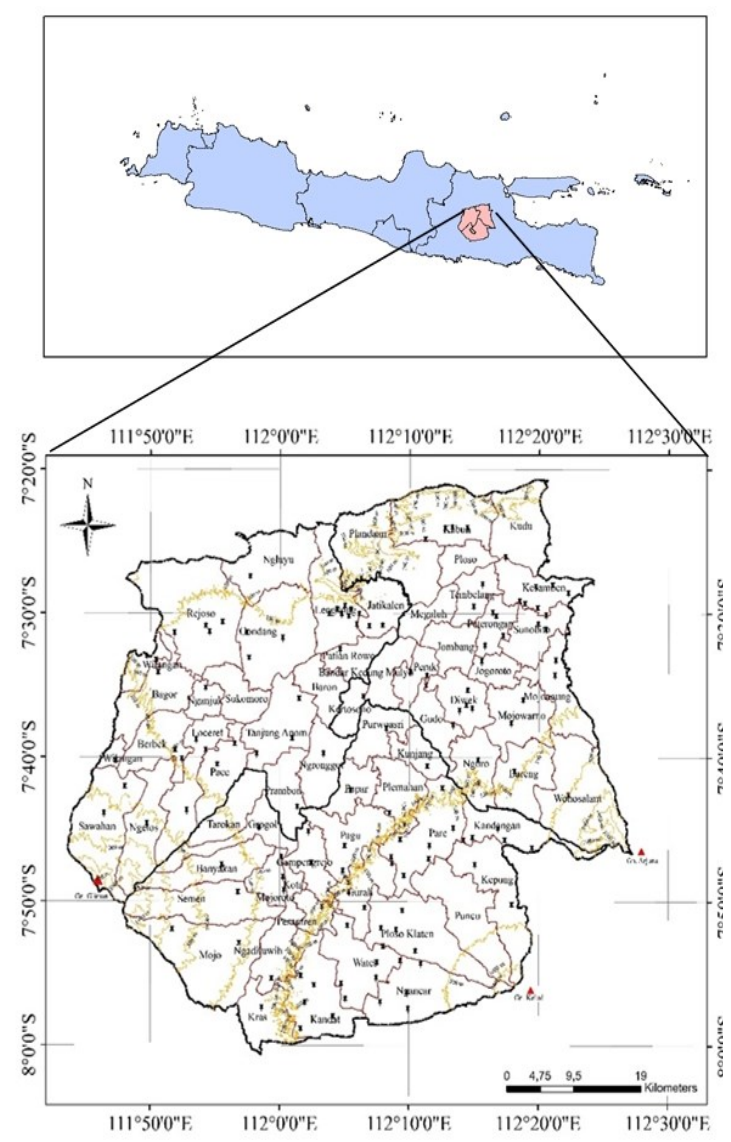

Gambar 1. Lokasi Penelitian

\section{Alat dan Bahan}

Data hujan yang digunakan dalam penelitian ini merupakan data hujan harian dari 137 unit penakar hujan yang didapat dari UPT PSDA di Kediri. Data hujan harian dijumlahkan menjadi data hujan bulanan dan hujan tahunan selanjutnya diformat ke file txt. serta di-import ke Software GIS.

\section{Prosedur}

Identifikasi untuk tiap kolom dalam tabel dijelaskan sebagai berikut. Kolom ke1 adalah ID yaitu nomor urut identifikasi 
atau banyaknya data. Kolom ke-2 menunjukkan kode stasiun di dalam database. Kolom ke-3 adalah nama stasiun. Kolom ke-4 menunjukkan koordinat mT (meter timur) atau koordinat (x) dan kolom ke-5 = mU (meter utara) atau koordinat (y). Selanjutnya, kolom ke-6 = El atau (elevasi) yang menunjukkan ketinggian lokasi stasiun hujan (meter). Kolom ke-7 adalah Pr (periode rekam) mewakili jumlah data yang tersedia pada setiap stasiun (tahun). Kolom ke-8 adalah hujan tahunan minimum atau Hthn_min (mm/tahun). Kolom ke-9 adalah hujan tahunan maksimum atau Hthn_min $(\mathrm{mm})$. Kolom ke-10 adalah hujan tahunan rata-rata atau HThn-rrt (mm). Kolom ke-11 adalah HRB atau hujan rata-rata bulanan (mm/bulan). Kolom ke-12 adalah HB_maks atau hujan bulanan maksimum ( $\mathrm{mm} / \bar{b}$ ulan) (Shiddiq et al., 2018).

Tahap selanjutnya adalah analisis data menggunakan ESDA (Exploratory Spatial Data Analysis). Analisis ESDA digunakan untuk eksplorasi, mengevaluasi data sehingga dapat diketahui karakteristik statistik datanya dan didapatkan gambaran distibusinya sebelum di interpolasi. Tools ESDA yang digunakan dalam penelitian ini mencakup: (1) Histogram, (2) Voronoi Map, dan (3) Normal QQ-Plot. Selanjutnya, peta variabilitas spasial hujan dibuat dengan metode interpolasi IDW (Inverse Distance Weigthing) untuk hujan bulanan dan tahunan (Indarto et al, 2011; Indarto, 2013b).

Pada tulisan ini hanya dibahas variabel HB_Maks (Hujan bulanan maksimum) dan Hthn_maks (hujan tahunan maksimum). Kedua variabel menunjukkan kondisi hujan ekstrem pada suatu wilayah dalam jangka waktu yang lama. Lokasi studi juga terletak tiga gunung yaitu Gunung Wilis, Kelud, dan Arjuna (Kominfo, 2016). Adanya perbedaan ketinggian tempat (lokasi stasiun hujan) dapat digunakan untuk melihat adanya pengaruh elevasi terhadap besarnya hujan yang diterima pada suatu wilayah. Hubungan antara elevasi dengan besarnya hujan dianalisis secara statistik menggunakan korelasi dan regresi. Jika elevasi dan besarnya hujan berkorelasi sangat kuat, analisis dilanjutkan dengan analisis regresi yang bertujuan untuk mengetahui besarnya pengaruh dari perubahan X terhadap Y.

Koefisien korelasi dilambangkan dengan $r$ (Persamaan 1).

$r=\frac{\left(\sum \mathrm{XY}\right)-\left[\left(\sum \mathrm{X}\right)\left(\sum \mathrm{Y}\right) / \mathrm{n}\right]}{\sqrt{\left[\left(\sum \mathrm{X}^{2}\right)\left(\sum \mathrm{Y}\right)^{2} / \mathrm{n}\right]-\left[\left(\sum \mathrm{Y}\right)^{2} / \mathrm{n}\right]}}$

Menurut Kismiantini (2010) dan Siregar (2015), tanda plus atau minus menunjukkan kemiringan garis regresi (positif atau negatif). Nilai koefisien korelasi antara $-1 \leq$ $r \leq 1$. Bila hubungan linear antara $X$ dan $Y$ sempurna maka $r= \pm 1$.

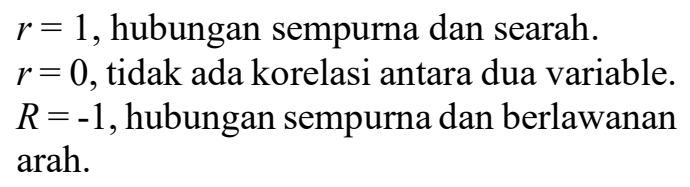
arah.

Koefisien determinasi (KD) merupakan sumbangan dari $\mathrm{X}$ terhadap variasi (naik turunnya) $\mathrm{Y}$, dengan Persamaan 2.

$\mathrm{KD}=(\mathrm{r})^{2} \times 100 \%$

Terdapat tiga dataran tinggi (Gambar 2) pada wilayah tersebut, yaitu Gunung Wilis disebelah barat, Gunung Kelud di Selatan, dan Gunung Arjuna di sebelah timur. Kemudian wilayah dibagi menjadi tiga kelompok yang digambarkan oleh 3 poligon bergaris putus-putus. Luasan dan bentuk tiap kelompok poligon dipengaruhi oleh bentuk dan ketinggian wilayah. Tiap kelompok memiliki wilayah dataran tinggi, sedang, dan dataran rendah. Kemudian dipilih stasiun hujan yang mewakili pada masing-masing ketinggian. 


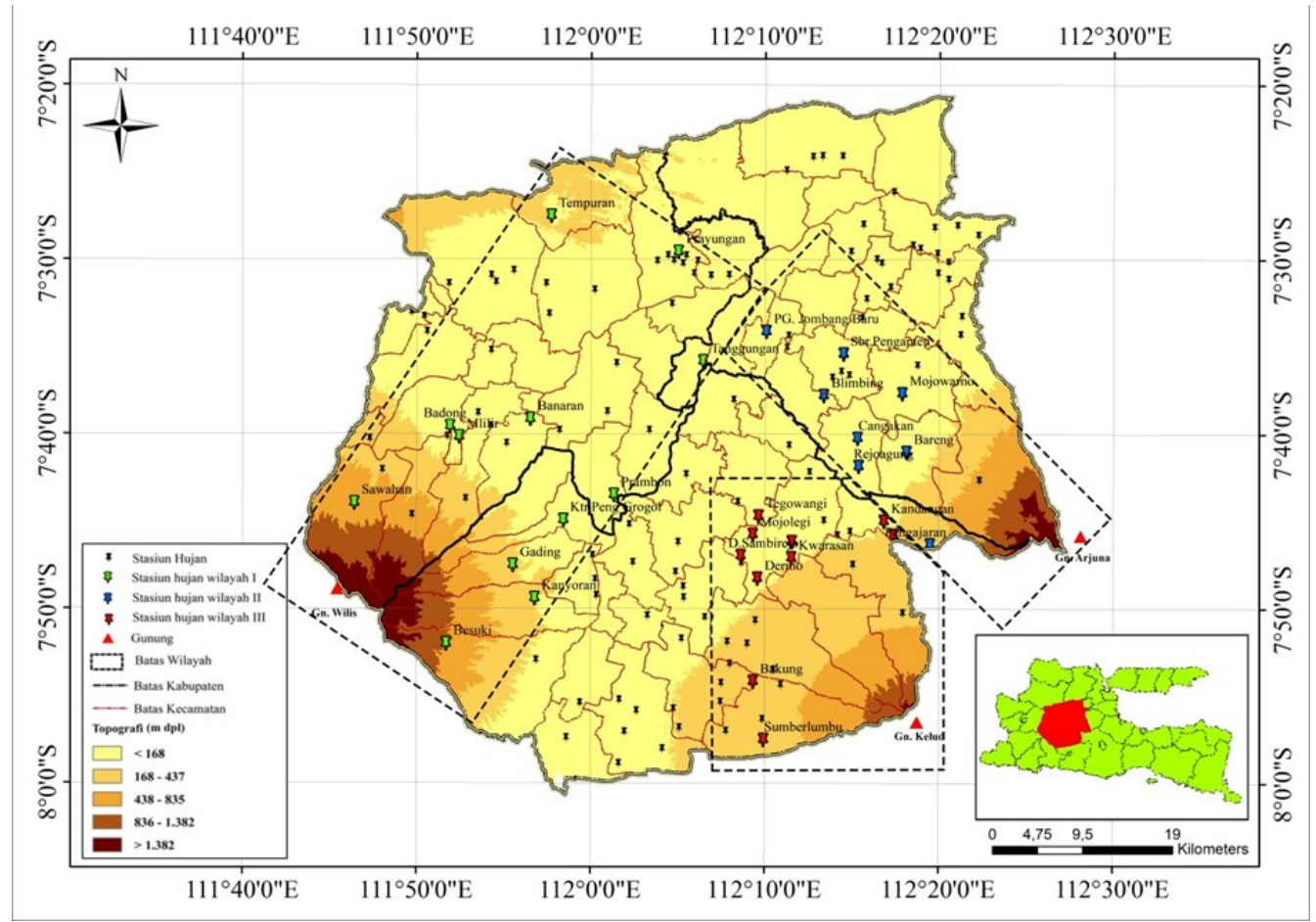

Gambar 2. Peta pembagian wilayah stasiun

Dari setiap poligon (Gambar 2), dipilih beberapa stasiun hujan sebagai sampel yang mewakili masing-masing ketinggian untuk uji korelasi-regresi.

1) Wilayah I ditunjukkan dengan titik berwarna hijau, sebagian besar stasiun terletak di Kabupaten Nganjuk dan beberapa stasiun terletak di Kabupaten Kediri.

2) Wilayah II ditunjukkan dengan titik berwarna biru, sebagian besar stasiun terletak di Kabupaten Jombang dan satu stasiun terletak di Kabupaten Kediri.

3) Wilayah III ditunjukkan dengan titik berwarna merah, stasiun tersebut terletak di wilayah Kabupaten Kediri.

Uji korelasi dan regresi dapat digunakan untuk menggambarkan adanya hubungan antara topografi dengan besarnya hujan yang turun pada suatu wilayah. Data yang digunakan adalah elevasi atau ketinggian stasiun hujan sebagai variabel bebas (x) dan data hujan sebagai variabel terikat (y). Selanjutnya, data hujan dari stasiun sampel tersebut dihitung untuk mendapatkan nilai koefisien korelasi (r) dan menentukan tingkat kekuatan hubungan antara elevasi dengan besarnya hujan.

Data yang digunakan untuk analisis korelasi regresi hanya data rata-rata bulanan dan rata-rata tahunan. Hal tersebut dikarenakan kedua data dapat mewakili data yang stabil (tidak menampakkan perubahan yang signifikan ketika terjadi perubahan nilai sample).

\section{HASIL DAN PEMBAHASAN}

\section{Histogram}

Gambar 3 memperlihatkan contoh histogram hujan bulanan di daerah penelitian.

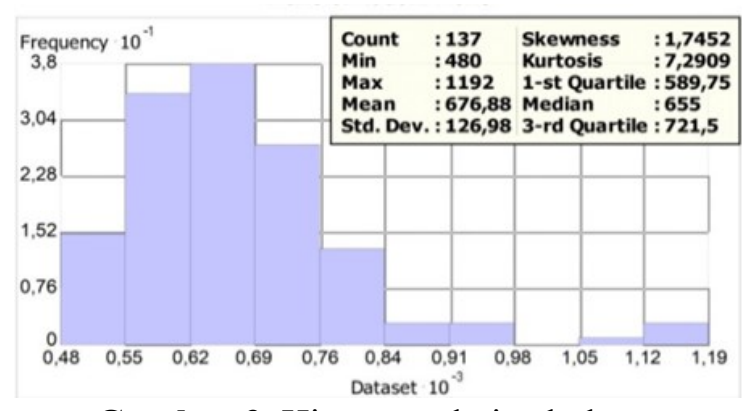

Gambar 3. Histogram hujan bulanan maksimum 
Sumbu X merupakan interval kelas data. Data yang tersedia dibagi menjadi sepuluh kelas. Angka $10^{-3}$ pada dataset menunjukkan bahwa nilai sebenarnya $=$ nilai sumbu $\mathrm{X}$ dibagi dengan $10^{-3}$. Frequency pada sumbu Y menunjukkan jumlah stasiun hujan yang masuk ke dalam tiap kelas interval. Nilai sebenarnya $=$ nilai pada sumbu y dibagi dengan $10^{-1}$.

Pada histogram, variabel "Count" menunjukkan jumlah data yang digunakan untuk analisis $=137$ stasiun. Mean $=$ nilai rerata hujan bulanan $=676,8 \mathrm{~mm}$ per bulan . Median menunjukkan nilai tengah $=655$ $\mathrm{mm} /$ bulan. Std.Dev atau Standar deviasi $=$ 126,98 . Nilai skewness $=1,75$, menunjukkan kemencengan distribusi data. Distribusi cenderung menceng ke kiri. Distribusi normal nilai skewness $=3.0$. Nilai kurtosis 7,29 menunjukkan bentuk histogram yang relatif tumpul. Beberapa stasiun yang memiliki nilai hujan bulanan ekstrem, antara lain: stasiun Blimbing dan Sapon di Kabupaten Jombang, serta stasiun Besuki dan Kandangan di Kabupaten Kediri.

Gambar 4 menampilkan histogram hujan tahunan maksimum. Nila rerata $=$ 3.065,5 mm/tahun. Median = 2.953 $\mathrm{mm} / \mathrm{tahun}$ dan Std.Dev $=629,18$.

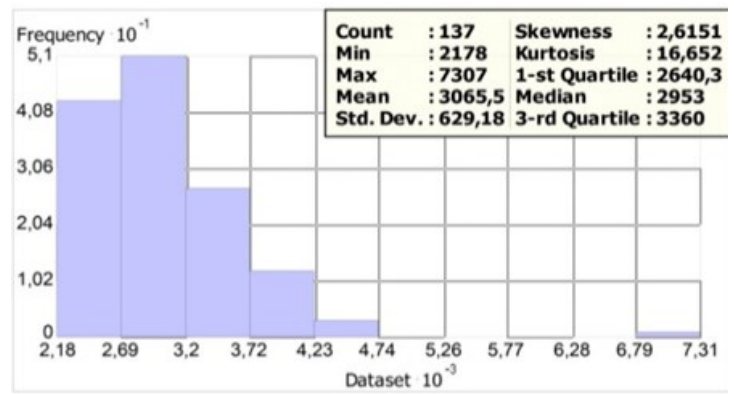

Gambar 4. Histogram hujan tahunan maksimum

Histogram cenderung ke kiri dengan nilai skewness 2,62. Beberapa stasiun yang memiliki nilai ekstrem, antara lain: stasiun Pengajaran di Kabupaten Jombang; serta stasiun Besuki, Mojo, dan Simbar yang terletak di Kabupaten Kediri.

\section{Voronoi Map HB_Maks}

Gambar 5 (a) sampai dengan (d) memperlihatkan variabilitas spasial hujan bulanan maksimum yang dianalisis menggunakan voronoi map. Voronoi map ini dapat dikelompokkan menjadi:

1) Local smoothing, berfungsi untuk meratakan distribusi antar poligon voronoi menggunakan nilai mean (Gambar 5.a) dan median (Gambar 5.b). Local smoothing menghaluskan sebaran nilai distribusi antar poligon yang berdekatan, sehingga terbentuk beberapa zone.

2) Local variation, berfungsi menguatkan adanya variasi lokal menggunakan nilai standard deviation (Gambar 5.c). Local variation menghasilkan diagram voronoi yang lebih menonjolkan variasi lokal.

3) Local outliers, berfungsi memperlihatkan anomali data lokal. Local outlier dianalisis menggunakan cluster (Gambar 5.d). Local outlier ditunjukkan oleh poligon berwarna abu-abu. 


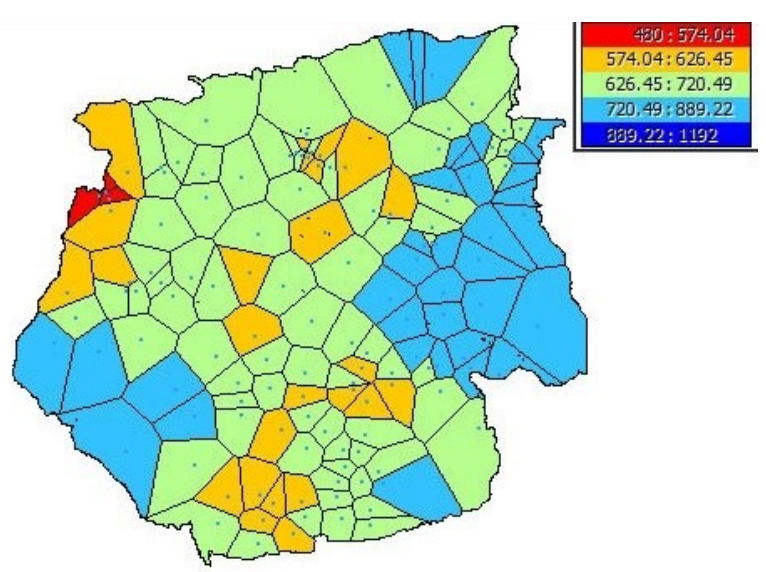

(a)

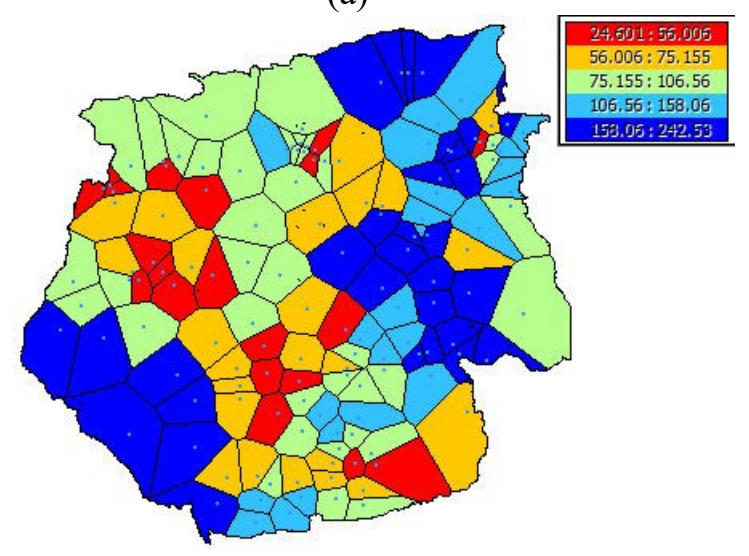

(c)

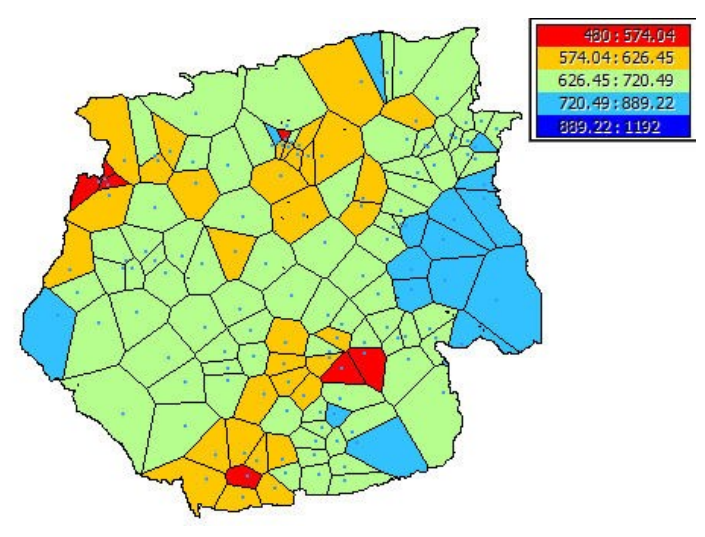

(b)

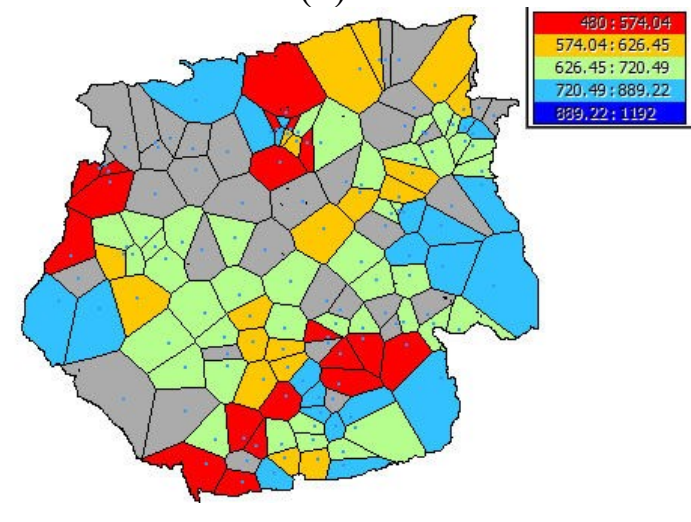

(d)

Gambar 5. (a) Mean, (b) Median, (c) Standar Deviasi, (d) Custer

\section{Normal QQ-Plot}

Normal QQ-plot membandingkan distribusi suatu seri data terhadap distribusi normal. Pada grafik Normal QQ-plot, seri data yang terdistribusi normal akan berimpit dengan garis distribusi normal. Gambar 6 dan Gambar 7 menunjukkan grafik Normal QQ-plot untuk hujan maksimum bulanan dan maksimum tahunan.
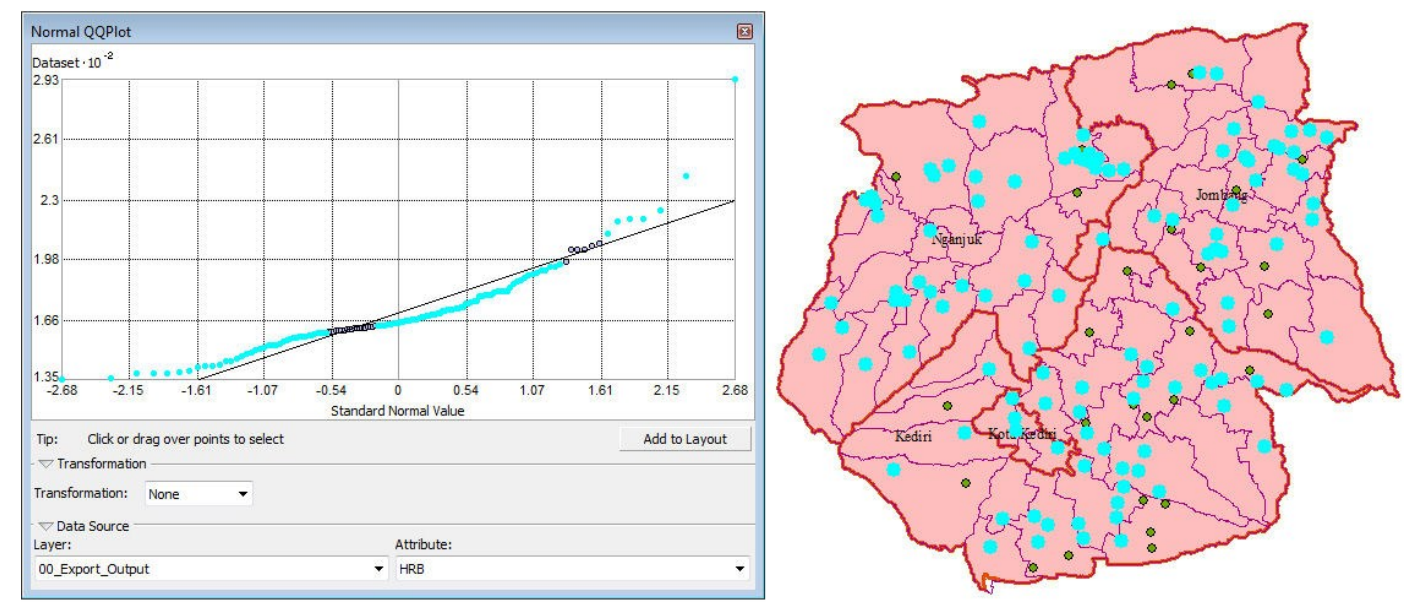

Gambar 6. Normal QQ-plot hujan bulanan maksimum 

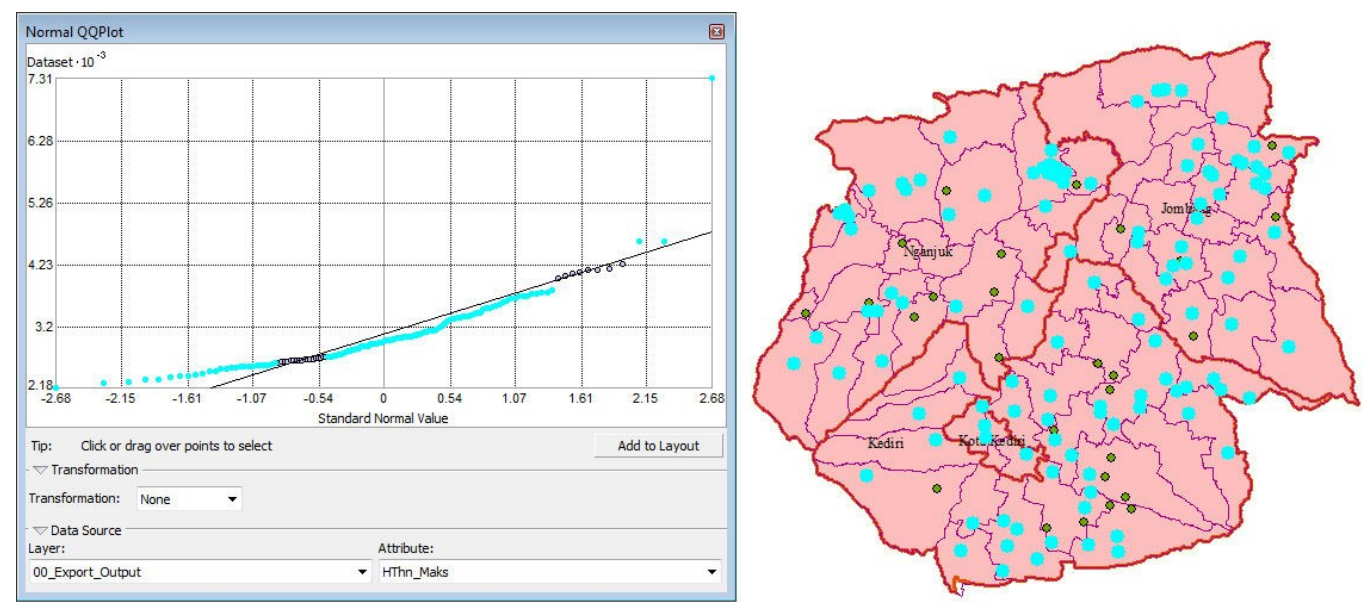

Gambar 7. Normal QQ-plot hujan tahunan maksimum

Kedua grafik (Gambar 6 dan Gambar 7) menunjukkan bahwa distribusi spasial hujan bulanan dan tahunan maksimum tidak terdistribusi normal. Titiktitik berwarna biru pada peta menunjukkan lokasi stasiun hujan yang nilainya berada di luar distribusi normal. Lokasi stasiun tersebut relatif menyebar di seluruh wilayah penelitian.

\section{Peta Tematik Hujan}

Hasil interpolasi $I D W$ untuk hujan bulanan maksimum ditampilkan pada Gambar 8. Terbentuk 5 kelas HB_Maks. Sebagian besar wilayah $( \pm 75 \%)$ menerima hujan bulanan maksimum antar $600 \mathrm{sd} 760$ $\mathrm{mm} /$ bulan dan tersebar hampir ke semua penjuru wilayah.

Beberapa wilayah kecamatan Rejoso, Wilangan, Bagor, Nganjuk, sukomoro, Kras, Kandat dan Ngadiluwih menerima hujan bulanan maksimum antara 450 sd 620 $\mathrm{mm}$ per bulan. Hujan bulanan maksimum yang lebih tinggi antara $761-900 \mathrm{~mm}$ per bulan diterima wilayah Kab. Jombang (mencakup: Mojoagung, Wonosalam, Ngoro, Bareng, Peterongan, Tembelang, dan Kesamben). Hujan ekstrem maksimum bulanan $>900 \mathrm{~mm}$ per bulan terjadi hanya di kecamatan Gudo dan Kandangan (di Kab. Jombang). Wilayah kecamatan Semen dan Mojo di Kab. Kediri juga termasuk yang menerima hujan ekstrem bulanan $>900$ $\mathrm{mm} / \mathrm{bulan}$.

Selanjutnya, Gambar 9 memperlihatkan peta hasil interpolasi IDW untuk hujan tahunan maksimum. Secara umum wilayah studi dapat dibagi menjadi dua kelas. Hujan tahunan maksimum antara $2.178-3.203 \mathrm{~mm}$ per tahun mendominasi hampir 70\% wilayah studi. Hujan ini mencakup sekitar $90 \%$ wilayah Kabupaten Nganjuk dan Jombang, dan sekitar 30\% wilayah Kabupaten Kediri. 


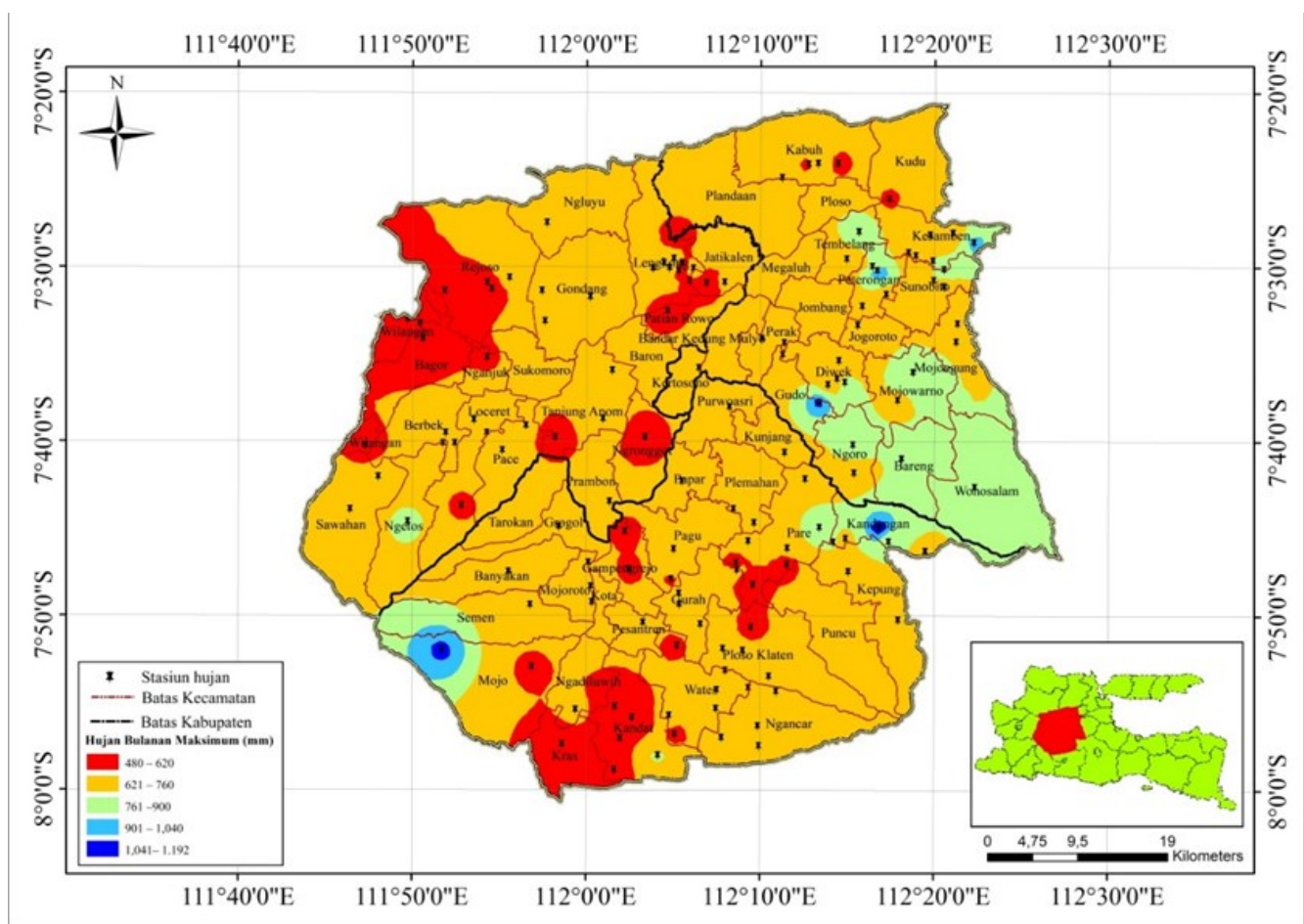

Gambar 8. Distribusi spasial hujan bulanan maksimum

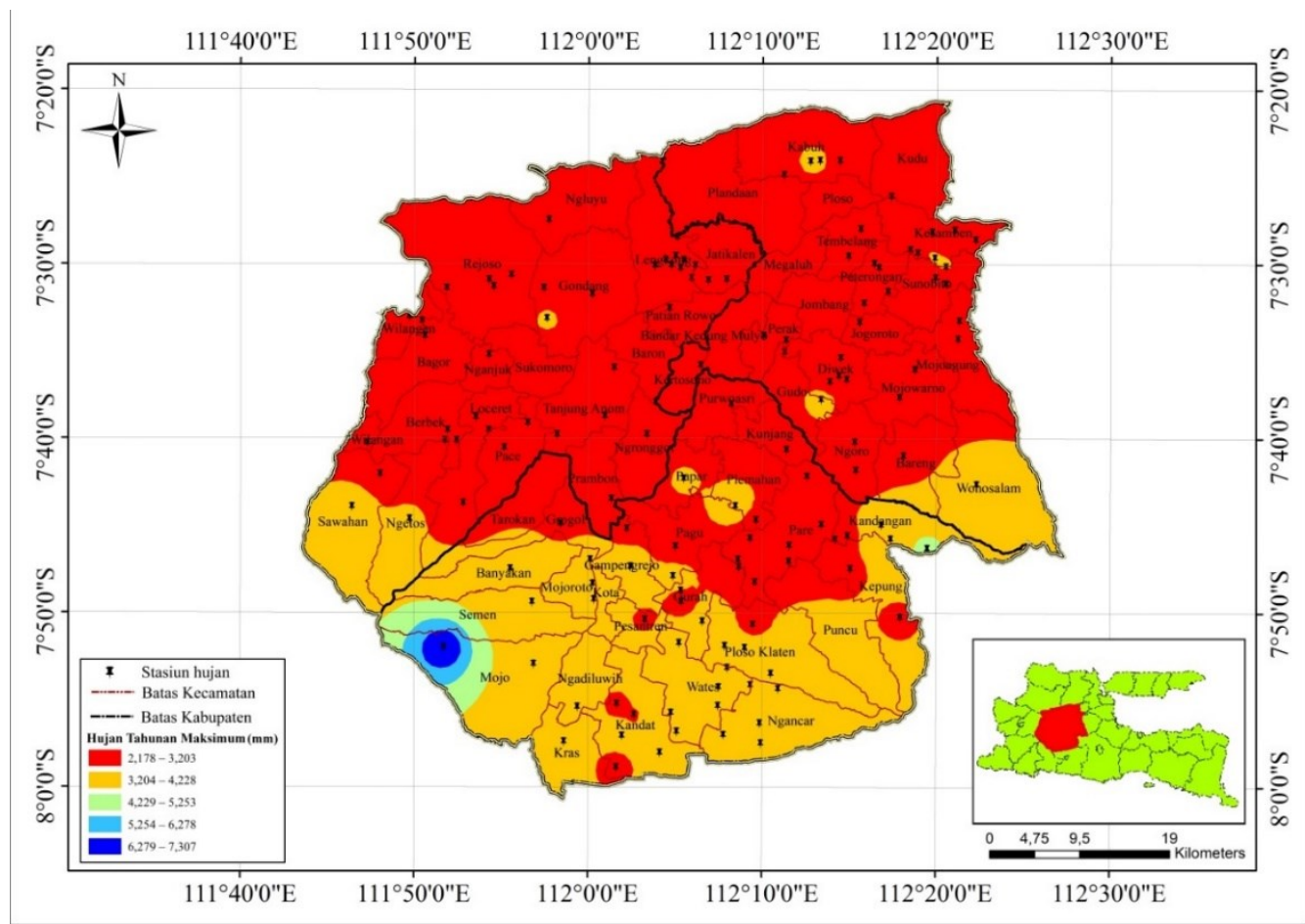

Gambar 9. Distribusi spasial hujan tahunan maksimum

\section{Pengaruh Topografi Terhadap Hujan}

Gambar 10 memperlihatkan hasil scatter plot antara ketinggian lokasi stasiun hujan dan besarnya hujan yang diterima pada ketiga lokasi sampel pada Gambar 2, yaitu: (a) wilayah I, (b) wilayah II, dan (c) wilayah III. Secara umum, Gambar 10 (a), (b), dan (c) menunjukkan bahwa elevasi dan curah hujan berbanding lurus, semakin tinggi nilai $X$ (elevasi stasiun hujan) maka nilai Y $(\mathrm{HRB}=$ hujan rerata bulanan) juga semakin tinggi. 

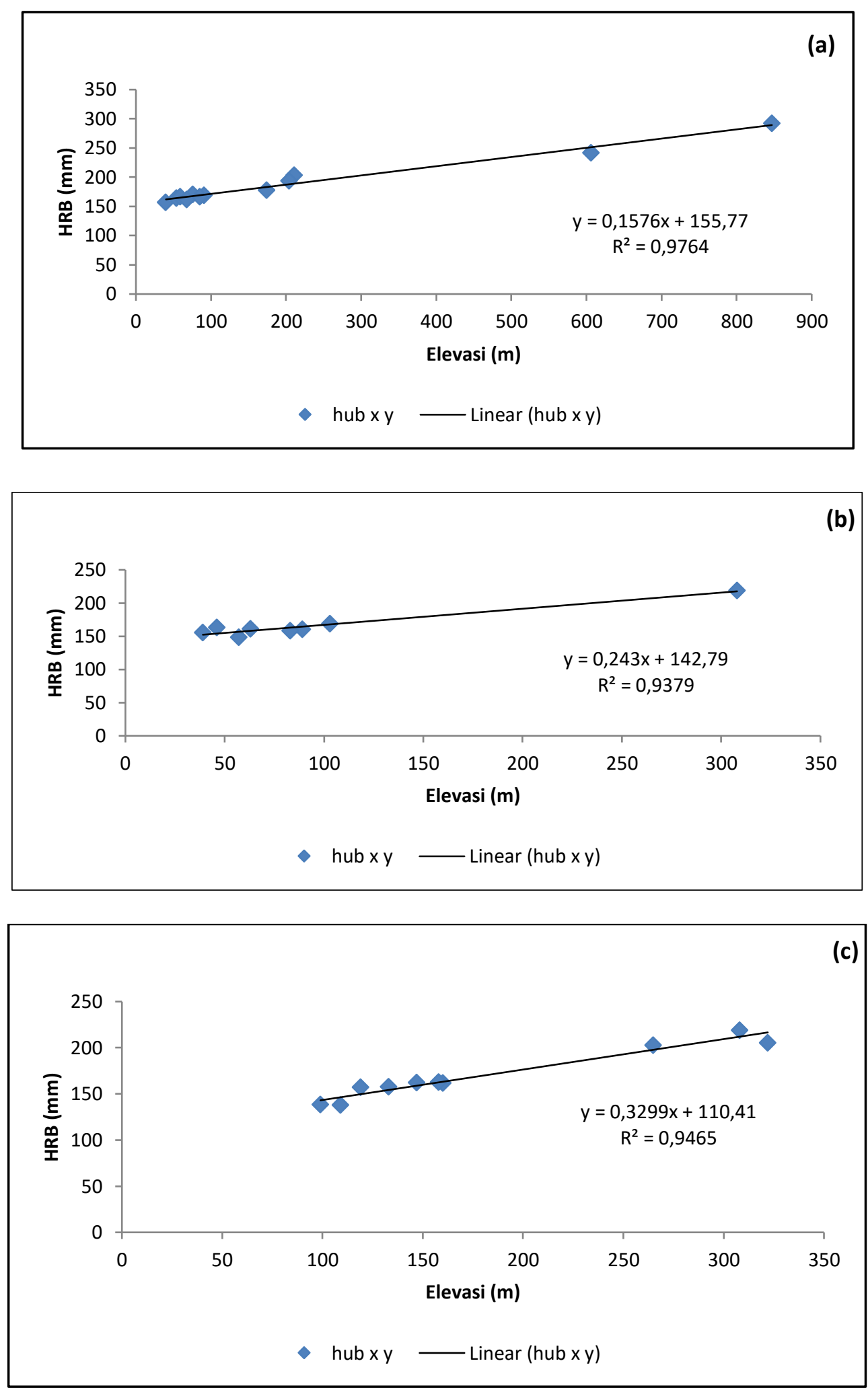

Gambar 10. Scatter plot hubungan elevasi dengan hujan rata-rata bulanan:

(a) wilayah 1, (b) wilayah 2, (c) wilayah 3

Gambar 10 (a) menunjukkan nilai $\mathrm{R}^{2} \quad=97,64 \%$, artinya elevasi berpengaruh $=0,97$ atau koefisien determinasi nya $(\mathrm{KD}) \quad$ sebesar $97,64 \%$ terhadap besarnya HRB. 
Nilai koefisien korelasi (r) sebesar 0,988. Nilai $r$ berada pada kisaran $0,80-1,00$ artinya tingkat hubungannya sangat kuat. Garis regresi y menjelaskan bahwa pada wilayah 1, elevasi mempengaruhi besarnya hujan sebesar $97,64 \%$ dan 2,36\% dipengaruhi faktor lain. Selanjutnya, Gambar 10 (b) menunjukkan nilai $\mathrm{R}^{2}=$ 0,9379 atau $\mathrm{KD}=93,79 \%$, artinya elevasi mempunyai pengaruh sebesar 93,79\% terhadap besarnya hujan. Nilai koefisien korelasi $(\mathrm{r})=0,968$ menunjukkan tingkat hubungannya sangat kuat. Pada wilayah 2, elevasi mempengaruhi besarnya HRB sebesar 93,79\% dan 6,21\% dipengaruhi faktor lain. Gambar 10 (c) menunjukkan nilai $\mathrm{R}^{2}=0,9465$; atau $\mathrm{KD}=94,65 \%$ artinya elevasi berpengaruh $94,65 \%$ terhadap besarnya HRB. Nilai koefisien korelasi (r) = 0,973 menunjukkan tingkat hubungannya sangat kuat. Garis regresi y pada wilayah 3 menyatakan elevasi mempengaruhi besarnya hujan sebesar $94,65 \%$ dan $5,35 \%$ dipengaruhi faktor lain.

Stasiun hujan yang berada pada elevasi lebih tinggi akan menerima hujan yang lebih besar. Hal tersebut dikarenakan udara yang mengandung uap air dari dataran rendah akan terbawa oleh angin ke tempat yang lebih tinggi, hingga mencapai titik kondensasi (membentuk awan), suhu yang lebih rendah pada dataran tinggi menyebabkan kumpulan awan tersebut menjadi titik-titik hujan. Sehingga terjadi hujan pada bagian lereng gunung yang berhadapan dengan arah datangnya angin. Hal tersebutlah yang menyebabkan dataran tinggi curah hujannya lebih besar dibandingkan dataran rendah. Kondisi ini berbeda dengan penelitian Prasetyo et al., (2018) yang mengamati bahwa curah hujan tertinggi di Sumatera Utara terjadi di daerah pesisir, sedangkan wilayah dataran tinggi dan pegunungan memiliki curah hujan lebih rendah.

\section{KESIMPULAN}

Hasil analisis menunjukkan adanya variabilitas spasial hujan wilayah Studi.
Hasil analisis menggunakan ESDA menunjukkan data hujan bulanan maksimum dan tahunan maksimum tidak terdistribusi normal. Sebagian besar wilayah penelitian berada pada rentang hujan bulanan maksimum antara $621-760 \mathrm{~mm}$ per bulan, dan rentang hujan tahunan maksimum antara $2.178-3.202 \mathrm{~mm}$ per tahun. Ketinggian stasiun hujan (elevasi) dan hujan yang diterima memiliki nilai korelasi (r) antara $0,80-1,00$ yang berarti tingkat hubungan keduanya sangat kuat. Artinya, elevasi atau topografi mempengaruhi besarnya hujan sehingga menyebabkan terjadinya variasi hujan.

\section{UCAPAN TERIMA KASIH}

Publikasi hasil penelitian ini di danai oleh Hibah Reworking - Skripsi, LP2M Universitas Jember tahun anggaran 2019. Terima kasih disampaikan kepada pihak UPT PSDA Kediri yang telah menyuplai data serta semua anggota tim (mahasiswa dan dosen TEP) yang telah membantu terlesaikannya penelitian ini.

\section{DAFTAR REFERENSI}

Arétouyap, Z., Nouck, P. N., Nouayou, R., Kemgang, F. E. G., Toko, A. D. P., \& Asfahani, J. (2016). Lessening the adverse effect of the semivariogram model selection on an interpolative survey using kriging technique. SpringerPlus, 5(1), 1-11.

Arfaini, J., \& Handayani, H. H. (2016). Analisa Data Foto Udara untuk DEM dengan Metode TIN IDW dan Krigging. J Tek ITS, 5, 2-7.

Coulibaly, M., \& Becker, S. (2007). Spatial Interpolation of Annual Precipitation in South Africa-Comparison and Evaluation of Methods. Water International, 32(3), 494-502. https://doi.org/10.1080/02508060708 692227. 
De Smith, M. J., Goodchild, M. F., \& Longley, P. (2007). Geospatial analysis: a comprehensive guide to principles, techniques and software tools. Troubador publishing ltd.

Ellouze, M., Azri, C., \& Abida, H. (2009). Spatial variability of monthly and annual rainfall data over Southern Tunisia. Atmospheric Research, 93(4), 832-839.

Feki, H., Slimani, M., \& Cudennec, C. (2012). Incorporating elevation in rainfall interpolation in Tunisia using geostatistical methods. Hydrological Sciences Journal, 57(7), 1294-1314.

Haberlandt, U. (2007). Geostatistical interpolation of hourly precipitation from rain gauges and radar for a largescale extreme rainfall event. Journal of Hydrology, 332(1-2), 144-157.

Hutchinson, M. F. (1998). Interpolation of rainfall data with thin plate smoothing splines. Part I: Two dimensional smoothing of data with short range correlation. Journal of Geographic Information and Decision Analysis, 2(2), 139-151.

Indarto, I. (2013). Analisis Geostatistik. Graha Ilmu, Yogyakarta.

Indarto, I. (2013). Variabilitas Spasial Hujan Harian di Jawa Timur. Jurnal Teknik Sipil, 20(2), 107-120.

Indarto, I., Diniardi, E. M., \& Susanto, B. (2011). Trend detection of rainfall data in East Java Region using MannKendal and Rank-Sum Tests. Jurnal Keteknikan Pertanian, 25, 1-21.

Indarto, Santoso, B., \& Diniardi, E. M. (2011). Analisis Kecenderungan Data Hujan di Jawa Timur Menggunakan Metode Mann-Kendall dan Rank-Sum Test. JTEP, 25(1), 1-10.
Johnston, K., Ver Hoef, J. M., Krivoruchko, K., \& Lucas, N. (2001). Using ArcGIS geostatistical analyst (Vol. 380). Esri Redlands.

Kampata, J. M., Parida, B. P., \& Moalafhi, D. B. (2008). Trend analysis of rainfall in the headstreams of the Zambezi River Basin in Zambia. Physics and Chemistry of the Earth, 33(8-13), 621-625.

https://doi.org/10.1016/j.pce.2008.06. 012

Kismiantini. (2010). Handout Analisis Regresi. Yogyakarta: Jurusan Pendidikan Matematika, Fakultas Matematika dan Ilmu Pengetahuan Alam, Universitas Negeri Yogyakarta.

Kominfo, D. (2016). Pemerintah Kabupaten Kediri, Kondisi Geografi Kabupaten Kediri. Retrieved from https://kedirikab.go.id/

Li, L., \& Revesz, P. (2004). Interpolation methods for spatio-temporal geographic data. Computers, Environment and Urban Systems, 28(3), 201-227.

Moges, S. A., Alemaw, B. F., Chaoka, T. R., \& Kachroo, R. K. (2007). Rainfall interpolation using a remote sensing CCD data in a tropical basin-A GIS and geostatistical application. Physics and Chemistry of the Earth, Parts $A / B / C, 32(15-18), 976-983$.

Naoum, S., \& Tsanis, I. K. (2004). A multiple linear regression GIS module using spatial variables to model orographic rainfall. Journal of Hydroinformatics, 6(1), 39-56.

Pasaribu, J. M., \& Haryani, N. S. (2012). Perbandingan Teknik Interpolasi DEM SRTM dengan Metode Inverse Distance Weighted (IDW), Natural Neighbor dan Spline (Comparison of 
DEM SRTM Interpolation

Techniques Using Inverse Distance Weighted (IDW), Natural Neighbor and Spline Method). Jurnal Penginderaan Jauh Dan Pengolahan Data Citra Digital, 9(2).

Pramono, G. H. (2008). Akurasi metode IDW dan kriging untuk interpolasi sebaran sedimen tersuspensi. Forum Geografi, 22(1), 97-110.

Prasetyo, B., Irwandi, H., \& Pusparini, N. (2018). Karakteristik curah hujan berdasarkan ragam topografi di Sumatera Utara. Jurnal Sains \& Teknologi Modifikasi Cuaca, 19(1), $11-20$.

Respatti, E., Goejantoro, R., \& Wahyuningsih, S. (2014). Perbandingan Metode Ordinary Kriging dan Inverse Distance Weighted untuk Estimasi Elevasi Pada Data Topografi (Studi Kasus: Topografi Wilayah FMIPA Universitas Mulawarman). Eksponensial, 5(2), 163-170.

Segond, M.L., Neokleous, N., Makropoulos, C., Onof, C., \& Maksimovic, C. (2007). Simulation and spatio- temporal disaggregation of multi-site rainfall data for urban drainage applications. Hydrological Sciences Journal, 52(5), 917-935. https://doi.org/10.1623/hysj.52.5.917.

Shiddiq, D. G. A., Indarto, I., Wahyuningsih, S., \& Askin, A. (2018). Aplikasi histogram untuk analisis variabilitas temporal dan spasial hujan bulanan: studi di wilayah UPT PSDA di Pasuruan Jawa Timur. Jurnal Teknologi Pertanian Andalas, 22(1), $1-12$.

Siregar, S. (2015). Statistika Terapan untuk Perguruan Tinggi. Jakarta: Kencana.

Tobin, C., Nicotina, L., Parlange, M. B., Berne, A., \& Rinaldo, A. (2011). Improved interpolation of meteorological forcings for hydrologic applications in a Swiss Alpine region. Journal of Hydrology, 401(1-2), 7789.

Zhang, X., \& Srinivasan, R. (2009). GISBased Spatial Precipitation Estimation: A Comparison of Geostatistical Approaches 1. JAWRA Journal of the American Water Resources Association, 45(4), 894-906. 